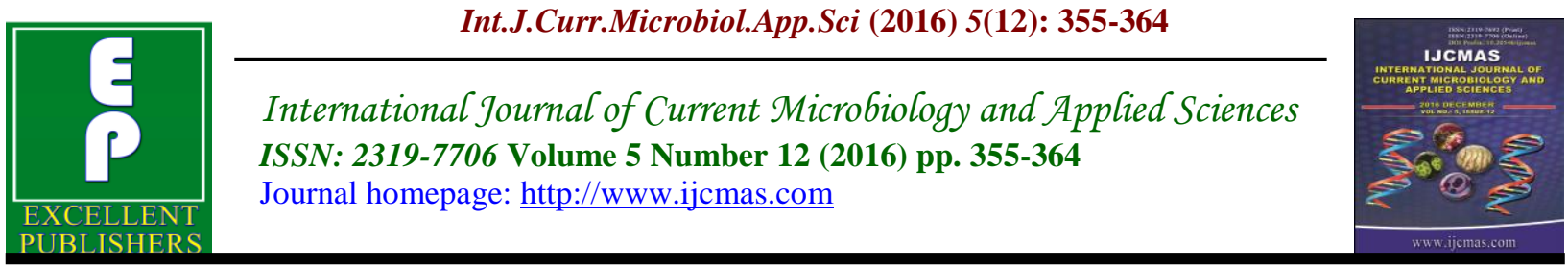

Original Research Article

http://dx.doi.org/10.20546/ijcmas.2016.512.038

\title{
The Life Quality Index of Coniferous Plants Introduced in Absheron Region
}

\author{
A.N. Seyidova ${ }^{1}$ and S.J. Ibadullayeva ${ }^{2} *$ \\ ${ }^{1}$ Baku Slavic University, Department of Primary Education, Azerbaijan \\ ${ }^{2}$ Institute of Botany of ANAS, Azerbaijan \\ *Corresponding author:
}

A B S T R A C T

\begin{tabular}{l} 
Key w or d s \\
Conifers, \\
Life quality \\
index, \\
landscaping. \\
\hline Article Info \\
\hline Accepted: \\
18 November 2016 \\
Available Online: \\
10 December 2016
\end{tabular}

Date about life quality index(LQI) of some species of coniferous plants introduced in parks, alleys, polluted territory of Apsherone areas have shown in the paper. In results of researches have been established that life quality index of different species of coniferous plants in ecology clean area and technogene polluted terrutory are not in the same level. So, in the park and alleys meets 458 specise with coefficient 100-80\% - "healthy", 4 species with coefficient $69-56 \%$ - "weakened", 8 species with coefficient $49-20 \%$ "strong weakened" and on polluted areas and roadsides under influence of gas and dust 25 species with coefficient $19 \%$ - "completely destroyed".

\section{Introduction}

Biodiversity - one of the fundamental concepts of theoretical biology, primarily reflects the theoretical basis of evolution. Cultural and wildbiodiversity constantly exposed to natural history, ecology and antropogen factors. So, the species from the concre floras which are needed to preserve must be found and cultivates.

The role of city planting trees refining environment, the creation of a unique microclimate conditions, absorption of technogene pollutants, improving the role of moral and psychological situation is obvious. World scientists (Isgenderova, 2011; Dubovik, 2011; Rogozhina, 2005; Rumelhart, 1989) have been established at the level of the biosphere the importance of abiotic environmental factors in the biological control research. According to this concept biotic components of the environment were destroyed in big cities and large industrial enterprises and the relative stability of biota and the fragile stability of environment are weakening and in results multiply points of biosphere have injured.

Taking into account the role of plantation in the environmentalarea, selection of the plants used in cities and towns, the taxonomic composition of the enriching and maintaining and high level of activity in their life are great importance. Keeping of hige level of life quality of plants is very important process for 
planting processe. So, the goal of the research was to determine the lifr quality index of coniferous trees, grown in conditions of Apsheron area.

\section{Materials and Methods}

The researches was carried out in 20152016years in the territory of Absheron. Material collected by the comparative route methods and many biometric measurements of ontogenic. conditions of plants were carried out concerning the situation. Observations of the objects of study have been implemented in the different polluted level parts of area, parks and alleys. Herbarium heve been collected from the territories, maked a lot of pictures, as well as were held researches in halfstationaryregime.

The scientific results of research for this species can be analyzed as tripartite relations"human-nature-ecological status", as well as creates conditions for the development of reasonably on the basis of responsible reaction of plants.

Marked plants of area determined by Y.Q. Rusakovmethods (Rusakov, 2007).

Life quality index of plant (LQI) was determined by the following formula according to the V.A.Alekseyev (Alekseev, 1989) methods:

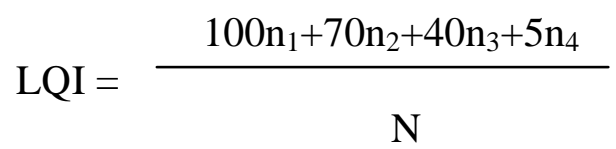

Here, $\mathrm{n}_{1}, \mathrm{n}_{2}, \mathrm{n}_{3}, \mathrm{n}_{4}$ - healthy, weakened, strongly weakened and the number of drying plants; $100,70,40,5$ - coefficient of lifequality level of healthy, weakened, strongly weakened and the drying plants, \%; $\mathrm{N}$ - the total number of plants from stationary.
During the research was considered that plants with coeffisient 100-80\% - "healthy", $79-50 \%$ - "weakened", 49-20\% - "strongly weakened", $19 \%$ and down - "completely destroyed".

\section{Results and Discussion}

Coniferous plants are introduced every year by hundreds of unitsin Absheron. Some of them is adapted to the new environment and continued development, while others are dying. The following information about the biological and ecological characteristics some of them was provided.

Cypress(Chamaecyparis Spach.) are a group of evergreen coniferous plants of Cypress (Cupressaceae Bartl Richex.) Family. Representatives of this group are distinguished by the two seeds in each cone flakes. Cones are spherical-shaped forms. Depending on the species, the size of the old plants up to $40-65 \mathrm{~m}$.

Cypress is free genus and unites 7 species. These are qualele (Ch.thyoides), yellow cypress (Ch.nootkatensis), Lavson cypress (Ch.lawsoniana), mourning cypress (Ch.funebris), formoza (Ch. Formosensis) sawara cypress (Ch.pisifera) and hinoki (Ch.obtusa) cypress and similar to the North American and East Asian origin. At present, lavson,sawara cypress, qualele,hinoki are more commonly used in parks and square. Twospecies from them -Ch.nootkatensis and Ch.lawsonianawere naturalizedin Azerbaijan flora.

However, new species of cypress have been shown different relation to new contrast conditions.So it just cypress species Ch.lawsoniana, normally conducts to city environment and were planted in Absheron parks and alleys, arong the roads. Other species are less resistant to influence of gas, 
dust and smoke. At the same time between the species was found different attitude to the soil type.

Lavson cypress - Ch.lawsoniana, maturing up to $65 \mathrm{~m}$ tall, with trunks $1,8 \mathrm{~m}$ in diameter. It has a nice decorative tree. Branches of tree are flakes type, flat, fragrant, strongly adherent to the branch, end part is dark green, light-colored base, margin glandular, on the side branches length of $2 \mathrm{~mm}$, and $6 \mathrm{~mm}$ on the size of the shoots below. Plant is monoecious, bisexual, blossoms in Spring. Cones are round, 6-1 $\mathrm{mm}$ in diameter, initially green, reaches brown, sometimes with a hint of blue are composed from 6-10 flakes. 2-4 seeds are in each flakes. Resistant to shadow. Plant does not like the chalky soil and normal growing in deep plowing layer and wet sandy soils with $\mathrm{pH}=4,5-5,5$. Suffers from drought. Sustainability to city environmental satisfactory. The young shoots can be destroyed at a temperature of $-30^{\circ} \mathrm{C}$. The young plants are required to cover in the first sowing year. Lives up to 600 years or more.

Sawara cypress - Ch.pisifera, fir-needles and cones are beautiful anddecorative. Leaves in flakes forms, pointed, dark green in the upper part and blue-and-white color in lower part. Plant is monoecious, bisexual. Blossoms in the Spring. Dark brown cones are small, round-shaped,up to $6 \mathrm{~mm}$ in diameter and consist from 10-12 flakes with $1-2$ seeds in eachflakes. Plant grows in the first year.

Plant good growsin the fertile and moist soils, $\mathrm{pH}=4,5-5,5$ and does't like the chalky soil. Photophilous plant. Plant does't resistant to city environment, especially to smoked. Plants are resistant to frost in Southern countries. Bring to frost up to $25^{\circ} \mathrm{C}$. The young plants are required to cover in the first sowing year. Plant is high need to light. Lives up tomore than 300 years.

Qualele- Ch.thyoidesmaturing up to25 m tall, with trunk $0,6-1,0 \mathrm{~m}$ in diameter.For fine upper branchesform, different color of firneedles and small decorative conesare widely used. Dark blue or light green color and densely arranged. Plant is monoecious, bisexual. Oblong-shaped yellow male flowers. The female flowers located in the side branches. Blossoms in March-April. Changes color depending on growing conditions. It's usually blue or brown colour. Plant is good growing in humid, peaty or sandy soils and worse in sand and dry soils. Lives up to 1000 years and more.

Hinoki - Ch.obtusa, maturing up $40 \mathrm{~m}$ tall, with trunks $2 \mathrm{~m}$ and more in diameter. Firneedles are dark green and densely arranged. Plant is monoecious, bisexual. Wrinkle numerous cones are the peas size. Blossoms in the Spring. Colorsof cones are orange or brown and cone-shaped, length by $1 \mathrm{sm}$.

It becomes a decorative appearance throughout the year.The normal growing in fertile soils, $\mathrm{pH}=4,5-5,5$. Photophilous plant. Lives up to200-300 years.

Juniper - Juniperusrefers toJuniper family.It has more than 60dioecious and monoecious species. Evergreen, coniferous trees and shrubs. Between grown plants took place conventional (J.communis), horizontal (J.horizontalis) and savin (J.sabina) species. "Compressa" sort of J.communis species, "Blue Clip" sort of J.horizontalis species, "Broadmoor" sort of J.sabinaspecies, "Spartan", "Blue Point", "Keteleeri" sorts of J.chinese species are growing in Khan garden and park by name of F.Amirov. Beetween this speciesJunipers ordinary is more sensitive. The other two species normally carries the urban environment. In 
general, each of the three species are suitable for widespread use in landscaping. Basic analysis indexof Juniperspecies.

Juniper ordinary -J.communis female flowering plants up to 3-5 $\mathrm{m}$ tall, diameter of crown $-3-5 \mathrm{~m}$, male flowering plants up to $5-8 \mathrm{~m}$ tall, diameter of crown-1,5 $\mathrm{m}$. Beautiful attractive looks. The leaves are thorny, dense, sharp end, 8-12 mm long. Upper side of the leaf has bluecolour stripe.Leaves collected in the launches of three pieces on each branch. Blossom in late April to first part of May. Plant is dioecious, but some representatives have male and female flowers on the one plant. Fruit cones arerounded or cylinder-shaped. Fruit ripening up to $8 \mathrm{~mm}$ in diameter,at first green, ripe fruits are dark green color. Till 23 process of vegetation is being developed. Each fruit cones are 1-3 units of seeds. In general, plant is less demandingto the soil type, even is growing in infertile stony and sandy soils. Prefers slightly acidic soils and don't resistant to saline soils and dry winds. Drought-resistant. To go into the shade, but normal growing in the light conditions. Plant ishighly sensitive to polluted air, so use of its in urban gardenshinders the wide. Frostresistant species. Plants are required to cover in the first sowing year. Whether it lives up to the 2000 long-lasting.

Waukegan creeping juniper-J.horizontalis, maturing up to $20 \mathrm{sm}$ tall, diameter is 1,5$1,8 \mathrm{~m}$. According to fir-needles and bush form looks beautiful. Green or blue color, 3$5 \mathrm{~mm}$ long. Fet-needles are brown color in autumn and winter. Blossoms in May. Ripe fruit cones are dark blue, sometimes it becomes black, diametrs 5-6 $\mathrm{mm}$, globeshaped.

Plant is less demanding to the soil, but more favorable to the sandy soils. Shadow resistant. Plat is growing best in urban environment. South and middle belt states are resistant to frost. The young plants are required to cover in the first sowing year. Plant lives up to 300 year.

Savin-J.sabina bush wich branches grow vertically up to 3-5 $\mathrm{m}$ tall. Bush has beautiful looks for the shape and color of thefir-needles. The leaves come in two types: the young plants have fir-needles of upright, 4-6mm long, the end of blue-green, fleshy; leaves of mature plants are flakes form. Blossoms in May. Fruit cones was oval shaped, 5-12mm long, blue-covered brown and black, the 1-6 pieces ofseeds are poisonous.It is being developed for the 2-3 vegetation times. Plant is less demanding tothe soil. Lime, sand, sandy soils, rocky mountain slopes are normal for the plant growing. Photophilous plant. Resistant to the gas and smoke. Plant showes a high resistance to frost in all regions. The young plants are required to cover the first sowing year. Plant lives up to 500.

Cedar (Cedrus Trev.) and trees refers to thePinefamily (Pinaceae Lind.)are differentheight. They create a sprawling pyramid or sprawling wide crown. Firneedles are three or four cornered, tough, depending fromspeciesare the bluish-green or silver-gray color. Blossoms in Autumn. New brought ornamental plants species Atlas cedar and Cedar of Lebanon also received wide coverage area. Stacked "Fasigiata" sorts and hanging sunshade "Glauca Pendula" sorts of Atlas cedar species, "Beacon Hill" sorts of Lebanese cedar species with narrow cone hanging, as well as the "Aurea" sorts of Himalayan cedar(deodar) have conical top part are distributed in park and airport territory of Absheron.

Himalayan cedar (deodar)-C.deodara, maturingup to 50 meters tall, with trunk about $3 \mathrm{~m}$ belowin diameters. For crown forms and fir-needles have decorative view. 
Fir-needles are long $(25-50 \mathrm{~mm})$, soft, thin, blue tinge of silver-green colour. collected into bundles.Blossoms in Autumn, pollen collapse in late October or beginning of November.

Fruit cones ovoid or oblong-egg sits upright branches, by 7-10 sm in length. Younger period is blue and then the red-brown color. Flakes located on main axis arranged densely, covering each other. This species of cedar less demanding to the soil. However, normal growing in the clay soils and resistant to clay. Requires high humidity in the air and soil, not resistant to water recession. Compared with other species is shade-resistant. City environmental sustainability is below. Frost resistance is higher, can survive short-term frost and temperatures down to $-20-25^{\circ} \mathrm{C}$ Decorative forms, and the young plantsare required cover crops in first sowing year in the winter time.Plant lives up to1,000years.

Atlas cedar - C.atlantica,tree up to $40-50 \mathrm{~m}$ tall. It has beautiful decorative view for color of fir-needles and forms of crown. Firneedles are blue-green, sometimes silverygray colored, 2,5 sm in length, located in a bunch by 30-40 units. Blossoms in Autumn. Fruit cones are bright, cylindrical in shape andegg forms by 5-7sm long. Plant is growing up till 3 years. Seedsare $12 \mathrm{~mm}$ and $15 \mathrm{~mm}$ long.

According to the literature, relatively frostresistant $\left(-20^{0} \mathrm{C}\right)$. Plant does not stand up to lime soil. Suffer from excessive wet soil and very picky to the light. Resistant to dust, gas and smoke. The young plants are required to cover the first sowing year.

Cedar of Lebanone- C.libani, plant up to25$40 \mathrm{~m}$ tall under natural conditions. For forms of crown and intensive colour of fir-needles has beautiful decorative view. Stiff needles are $15-35 \mathrm{~mm}$ long, dark green or blue-green color and going into bundles. Blossoms in Autumn. Dark brown cones individually located, tub-shaped and 8-10 sm long. Wide of flakes of seed - $5 \mathrm{sm}$. Cones grows in 3rd year. Seeds in length from $15-18 \mathrm{~mm}$ up to $25 \mathrm{~cm}$ long, winged. The seed keepingin cones up to 20 years.

Drought-resistant, not demanding to soil, tolerate to lime soil, but not resistant to wet soil. Light relatively demanding. City environmental sustainability below. Relatively frost-resistant species of cedar (short-term frost is going under- $30^{\circ} \mathrm{C}$ ), young plants is required cover the first year of culture,lives up tomore than 1,000 year.

European silver fir or silver fir(Abies Mill.) also refers to the Pine Family. Plant has slender body which creates straight trunk in youthful times. The old treewith trunk 0,5-2 $\mathrm{m}$ in diameter, the plant is up to $80 \mathrm{~m}$ tall.Tree has a dense crown. Sprouts of branches are flat and laid in two rows of shoots over the narrow, flat, blunt tip and covered by fir-needles. Fir-needles on upper partis the dark green, bright, light-colored and the white strip on the bottom side. Firneedles takes 8-15 years. Flowering are beginnings in 8-15 or $60-70$ years depending from conditions. The trees lives up to300500 years. Shade-resistant and demanding to humidity and soil.

Among them new "Nana" sort of Balsam fir, "Barabitc Compact" sorts of Caucasian fir, and Spanish firwere growng. Unfortunately, some species of Spanish fir died due to unusual environmental conditions.

Caucasian fir-A.nordmanniana Spach.,up to- $50-70 \mathrm{~m}$ tall, with trunk up to $2 \mathrm{~m}$ in diameter. For crown formsand dark green and dense arrangement of fir-needles have very beautiful decorative view.Fir-needles 
up to $4 \mathrm{sm}$ long, dark green, bright. The bottom side of the pair of bright white striped and crown reminds the silver. Firneedles are retained in the crown 9-13 years. Blossoms at the beginning of May, male flowers are reddish, young female flowers the first time have been raised slightly on the both sides and greenish color. Roundcylindrical shaped cones by 12-20 sm in length, with 4-5 sm in diameter. Under full maturation stay the brown color and gum. Three part are fold back and pointed tip.

It can not growin calcareous soils and prefer mix of high clay soils and blacksoils. Species are highly resistant to shade. But normal growing in the light also. City environmental sustainability below. Moderately resistant. Short-term frost and can absorb up to $-25^{\circ} \mathrm{C}$. The young plants are require to cover crops at the first year in winter. Long-lived, up to 500-800 years.

Balsam fir-A.balsamea,up to $15-25 \mathrm{~m}$ tall, with truck $0,5-0,8 \mathrm{~m}$ in diameter. Numerous dark purple colorcones are beautiful decorative view. Trees with dark green and fragrant fir-needles. Fir-needles in the the tip part - bright, whitish on the basis of double lanes. 1,5-3,5 sm in length. Fir-needles shoot each other over a few rowsand lives up to 5 years. Blossoms in the Spring. Grayishbrown color, rather resinous, round forms, 5-10sm long and 2,0-2,5 sm in diameter, cylindrical shape.

Fir-needles fall off in October. Seeds are small, winged, purple-brown color, 5-8 mm in length. Gives the high seed product in each 2-3 years. Crop yields of 20-30 years of age. Highly resistant to gas. In all regionsfrost-resistant. The young plants are required to cover in the first sowing year. Normal growing in wet clay soils. Shadowresistant.

Spanishfir - A.pinsapo, up to $25 \mathrm{~m}$ tall,with truck $1 \mathrm{~m}$ in diameter. For crown and fir- needles forms have decorative view. Firneedles are short $(15 \mathrm{~mm})$ and have in low basepart white double line. Blossoms in the Spring. Fruit cones are cylindrical, ovoid, $10-15 \mathrm{sm}$ in length, consist round flakes with seeds.Grows in October. Seeds dark brown, $7 \mathrm{~mm}$ long. Seed is twice, with long and light brown colored wings. It is less demandingto the soil, drought-resistant. But it is growing better on the sandy soils. Photophilous plant. City environmental sustainability below. The young plants are required to cover in the first sowing year. Lives up to 350 year.

Pine - Pinus L. genus refers to the Pine family. This genus includes 100 species. Tall trees (35-75 $\mathrm{m})$ and durable. Fir-needles looks as needles and keeping by 2-5 units in a bun. The female cones grow for two years period. Deep root systems and widespread. Light demanding, drought resistant. Plant don't afraid from snow, frost and winds.

Now using next species for landscape: veymut planting pine, mountain pine, European cedar pine, black pine and Engelman (hanging) pine.

Eldar pine - P.eldaricaMedw. Located on the right bank of the Iori river on the border Azerbaijan with Georgia, spread on territory of Eldar plain. Endemic of Azerbaijan. Up to $15-20 \mathrm{~m}$ tall, withspreading crown. It has a nice appearance. Blossoms in the Spring. Thick solid cones covered with flakes, hard drop. The seedsability to grow in the second year after flowering with high germination of seeds $-75-80 \%$. It is not demanding to the soil. Photophilous plant. City environment sustainability is high. Frost resistant $\left(-20^{0} \mathrm{C}\right)$. Plants are not required to cover in the first sowing year. Lives up to400 years.

Veymut pine or white pine-P.strobes L.,up to $40-50 \mathrm{~m}$ tall. "Fleecy"crownlooks nice. 
Fir-needlesare located in the thin by bunch (5 units), blue-greencolor, up to $10 \mathrm{sm}$ in length. Blossoms in April-May. Elongated cylindrical $(16 \times 4 \mathrm{sm}), 1,5 \mathrm{sm}$ long by 1-3 numbers. Exception saline soils can normal grow in different types of soil. Shadow resistant. Smoked and gas-resistant and also frost resistant. Young plant is required cover in first sowing year. Lives up to 400 years.

Mountain pine - P.mugo L.. timber plants, but also occurs in forms of bush-type and spread. For form of crown, fir-needles, and especially large yellow and pink male cones in flowering periodare beautiful decorative view. 2 units of fir-needlestoghether (3-8 sm) are sharp, intense and dark green color. It has a slightly curved shape and lives up to 2-5 years. Blossoms at the end of May, beginning of June. From 6-10 years of age begins to blossom and gives product. Cones will grow in November of next year. Each yeargives a strong crop yields. Light brown cones are short (2-7 sm), egg form,located by 1-3 pieces together. Seeds are small and dark color. It is not demanding to the soil. Drought-resistant. Relatively little resistance to shadow. City environmental sustainability satisfactory. Frost-resistant. The young plants are required to cover the first sowing year.Lives up to150-200 years.

Swiss stone pine or Arolla pine -P.cembra Don. Up to $10-25 \mathrm{~m}$ tall tree, with truck $1 \mathrm{~m}$ in diameter. For the fir-needlesand crown forms has beautiful decorative view. 5 pieces of fir-needles keeping together. Dark green color, enough stiff needles by12-15 sm long. Blossoms in April. Cones by 5-8 sm in length, erect trunk, with egg forms and short stalk. It growsin the second year. Seed length - $12 \mathrm{~mm}$, named "cedar cones". Produces heavy crops on the open areasfrom 25-35 years of age, on dense plantingsfrom50-60 years of age. Grows best in damp clay soils. Plant are demandingto air and soil humidity. Shadow and frost resistant. City environmental sustainability below. The young plants are required to cover the first sowing year. Lives up to 1,000 years.

Black pine-P.nigra Arnold. Lamb., up to 15-20 m tall, wide cone-shaped crown, with a $8-10 \mathrm{~m}$ in diameter. Usually for the isosceles triangle form has decorative view. Fir-needles are long (8-14 sm), dark green, shiny or matte. Stiff needles, toe pointed, straight or slightly curved, is basically hanging. Blossoms in late April and early May. Short stalk cones $(8 \times 3 \mathrm{sm})$ have horizontal position, yellowish-brown color, bright pops and up in the third year. Grows well in all soil types. However, trees are bad developt in poorly calcareous soils. Photophilous plant.Resistant to city environment. It is required to cover in the first sowing year. Lives up to 350-400 years.

Apache pine -P.engelmanii Sol. 20-30m tall, with truck $35-80 \mathrm{~m}$ in diameter. Firneedlesare long $(20-40 \mathrm{sm})$ in the group (with 5 being). At first time the green, then turn bright brown. Blossoms in the Spring. 28-30-year-old crop yields. Cones grows in two years, 10-20 sm long and yellowishbrown color.It has a nice decorative view. Plant is not demanding to the soil. Photophilous plant.Resistant to the city environment. Frost resistance,till high $40^{\circ} \mathrm{C}$. Plant does not require in cover crops in the first year. Lives up to130-150 years.

Yew (Taxus L.) have known 8 species belong to theTaxacées (Taxaceae S.F. Gray) family. Aboriginal origin - Berry yew species or Rot-prooftree distributed in south-eastern slopes of the Lesser Caucasus Mountains, in the Talysh Mountains. Among the brouth new species "Fastigiata Aureomarginata" and "Robusta Fastigiata" sorts are presents, they are good addition to the new city environment, but also distinguished by continuity in the shade. 
European or common yew - T.baccata L., up to 25-30 m tall. For forms of crowne, shell and leaves of the tree are the beautiful appearance. Fir-needles are dark green, flattened, including with sickle slightly bent and 3,5 sm in length, densely located on a branch. The upper part is bright. The bottom part - overcast, vertically with two open lanes. Takes up to 10 years on bruches. Blossoms in March and April. The seedsproduce at first time about 20 years of age. The female cones are located at the end of the branches under the fir-needles one by one.Seed grows in September. Each seed is red color and sweet taste. The tree is normal grows in lime, fertile, moist soils with welldrainage systems, but also can grow in clay soils. The young plants need a cover crop in the first sowing year in the winter. Lives up to 4,000 years.

Table.1 Life quality index (LQI) of coniferous in conditions of Apsherone

\begin{tabular}{|c|c|c|c|c|}
\hline \multirow[b]{2}{*}{ Species } & \multicolumn{4}{|c|}{ LQI, \% } \\
\hline & $\begin{array}{l}\text { Healthy } \\
(100-80)\end{array}$ & $\begin{array}{c}\text { weakened } \\
(79-50)\end{array}$ & $\begin{array}{c}\text { strongly weakened } \\
(49-20)\end{array}$ & $\begin{array}{c}\text { complete } \\
\text { destruction }(19<)\end{array}$ \\
\hline Abies normanniana & 4 & - & - & - \\
\hline A.balsamea & 12 & - & - & - \\
\hline A.concolor & - & - & - & 6 \\
\hline Cedrus libani & 15 & 1 & - & 2 \\
\hline C.atlantica & 4 & - & - & - \\
\hline C.deodara & 48 & - & - & - \\
\hline Chamaecyparisobtusa & 24 & - & - & - \\
\hline Ch.lawsoniana & 122 & 2 & 2 & - \\
\hline Ch.pisifera & 10 & - & 2 & - \\
\hline Ch.thyoides & 42 & - & - & - \\
\hline Juniperus communis & 26 & - & - & - \\
\hline J.horizontalis & 43 & - & - & 5 \\
\hline J.sabina & 38 & - & - & 4 \\
\hline Pinus cembra & 4 & - & - & - \\
\hline P.nigra & - & - & - & 3 \\
\hline P.engelmanii & 2 & - & - & - \\
\hline P.mugo & 6 & - & - & - \\
\hline P.strobus & 4 & 1 & - & - \\
\hline P.eldarica & 20 & - & 4 & 4 \\
\hline Taxus baccata & 6 & - & - & - \\
\hline T.cuspidata & 6 & - & - & - \\
\hline Thuya occidentalis & 14 & - & - & 1 \\
\hline Th.orientalis & 20 & - & - & - \\
\hline Total & 458 & 4 & 8 & 25 \\
\hline
\end{tabular}

Japanese yew-T.cuspidata L., up to 20mtall. For "Cascade" (waterfall)for of crownhas beautiful decorative view.Fir-needles by 1,8 -
2,6 $\mathrm{sm}$ in length, relatively light color. The upper part is the dark green, light green and the lower part - brown with double yellow 
lanes. Fir-needles are brown and fall slightly, lives up to 4-5 years. Blossoms in April and May. The seeds grow in August and September, looks similar as"cedar cones". Cons have round forms, egg-shaped elliptical, $3 / 4$ of cons cover - pink colour. Trees will produce a high seeds products every 5-7 years. Plant prefers sand, light soils. The young plants need cover crop in the first sowing year in the winter. Lives up to more than 2,000 years.

Some of these plants have been brought at the first time in our Republic. Cultivation of plants adapted to the new circumstances is determinated by their life quality index (LQI).

Investigations related to the study of this issue have been shown that all inroducent did not have the same life quality index.

As can be seen from the table.1, one group from 23 species belonging to 7 genus are hidh LQI depending from growing conditions and geographic strengths, while others demonstrate a relatively low LQI. Thus, in Apsheron conditions from ornamenatal coniferous plants from Pine (Pinus) genus - Black pine (Pinus nigra) species, from Fir (Abies) genus - White fir(Abies concolor) species were complete destruction, from 60 units of Eldar pine (P.eldarica) $20 \%$ also were complete destruction, and $20 \%$ - severely weakened condition.

At the same time, the Juniper genus 50 units of Waukegan creeping juniper(Juniperus horizontalis)species 11-12\%, from 45 units of Salvin (J.sabina) species $10 \%$ have been completely destruction. In general, from 500 representatives of planted coniferous vegetation, $1,5 \%$ is the strongly weakened, $4,7 \%$ have been completely wiped out.
The causes of strongly weakened and destruction of representative of Pine genus - the wrong choice of the landing site and the lack of irrigation - have been establish while investigating. So, representative of White fir (Abies concolor)was growing in the shadowy places where have not been enough fully provided by sunlight. Nearest to them, 5-6 units of Pinus nigrawere lost due to the high doses of irrigation.

Total LQI of coniferous plants in Apsherone $-92,5 \%$ can be high considered. So, appropriate to the widespread use ofspecies with high LQI for landscap and prevention of technogene pollution of Apsherone.

\section{References}

Alekseev, V.A. 1989. Diagnosis life conditions of tree stands // Forest Sci.,, № 4, pp. 51-54. (russian)

Dubovik, V.A. 2011. Environment improving techniques for improvement of habitat, and phytodesign and phytoindication // Subtropical and Ornamental Plants, VNIITS and the SK, Russia, AAS, issue 45, Sochi, pp. 270-273. (russian)

Isgenderova, T.H. 2011. Bioecological properties of new decorative coniferous plants used in Ganja city landscaping. // District Scientifical Centre of Ganja. "Kheberler" ("News") J., № 44, pp. 10-14. (azerb.)

Rogozhina, T.Y. 2005. Perspective of the introduction of decorative perennials in central Yakutia: Author. Of PhD dissertation. Yakutsk, $18 \mathrm{P}$. (russian)

Rumelhart, D.E. 1989. "The Architecture of Mind: A Connectionist Approach", in M. Posner (ed.) Foundations of Cognitive Science, Cambridge, MA: MIT Press, p. 133-159. 
Rusakov, E.G. 2007. Methods of studying

Univ. Public house "Astrakhan the flora and plantation. Astrakhan:

University", 55 p. (russian)

\section{How to cite this article:}

Seyidova, A.N., and Ibadullayeva, S.J. 2016. The Life Quality Index of Coniferous Plants Introduced in Absheron Region. Int.J.Curr.Microbiol.App.Sci. 5(12): 355-364.

doi: http://dx.doi.org/10.20546/ijcmas.2016.512.038 